\title{
ТЕОРЕТИЧНІ ОСНОВИ ФОРМУВАННЯ ГОТОВНОСТІ МАЙБУТНІХ ФАХІВЦІВ ІЗ ФІЗИЧНОГО ВИХОВАННЯ ТА СПОРТУ ДО ПРОФЕСІЙНОЇ ДІЯЛЬНОСТІ
}

\author{
Ольга Романчук ${ }^{1}$, Мирослава Данилевич ${ }^{1}$ \\ ${ }^{1}$ Львівський державний університет фізичної культури імені Івана Боберського, м. Львів, Україна, \\ olgabrvska@gmail.com
}

https://doi.org/10.29038/2220-7481-2019-01-14-21

\begin{abstract}
Анотації
Актуальність роботи зумовлена потребою чіткого розуміння та диференціації ключових понять і термінів для успішної практичної діяльності майбутніх фахівців із фізичного виховання й спорту. Мета статті - визначити теоретичні основи підготовки майбутніх фахівців із фізичного виховання та спорту до професійної діяльності. У ході дослідження передбачено виконання таких завдань: проаналізувати науково-методичну літературу 3 проблеми дослідження; вибрати та описати масив базових термінів, пов'язаних із підготовкою майбутніх фахівців із фізичного виховання й спорту до професійної діяльності. Для досягнення поставленої мети та виконання завдань дослідження використано комплекс методів дослідження, зокрема теоретичний аналіз, синтез, порівняння, систематизацію й узагальнення. Результати. На основі теоретичного аналізу та узагальнення даних енциклопедичної, довідкової й психолого-педагогічної літератури схарактеризовано основні поняття освітянської складової частини підготовки майбутніх фахівців із фізичного виховання та спорту до професійної діяльності. Зокрема, визначено сутність понять «заклад вищої освіти», «підготовка», «професійна підготовка», «професійна підготовка майбутніх фахівців із фізичного виховання й спорту», «професійна готовність», «готовність до діяльності», «готовність майбутніх фахівців фізичного виховання та спорту до професійної діяльності». У роботі опираємося на інтегровані чи запропоновані іншими науковцями визначення ключових понять. «Вища фізкультурна освіта» - це цілеспрямоване формування знань, умінь і навичок для засвоєння соціального досвіду досягнення фізичної досконалості. «Підготовка» - це процес, результатом якого є готовність. «Готовність» розглядаємо як «цілісну інтегровану якість особистості, що характеризує ії емоційно-когнітивну та вольову вибіркову прогнозуючу мобілізаційність у момент уключення в діяльність певної спрямованості. Під поняттям «готовність майбутніх фахівців фізичного виховання та спорту до професійної діяльності» розуміємо комплекс необхідних знань, умінь і здібностей, сформованих у результаті виховання та професійної освіти, структурними компонентами якої виступає психологічна, фізична, теоретична та практична готовність.
\end{abstract}

Ключові слова: фізична культура, поняття, готовність, професійна підготовка, професійна діяльність.

Ольга Романчук, Мирослава Данилевич. Теоретические основы формирования готовности будущих специалистов по физическому воспитанию и спорту к профессиональной деятельности. Актуальность работы обусловлена необходимостью четкого понимания и дифференциации ключевых понятий и терминов для успешной практической деятельности будущих специалистов по физическому воспитанию и спорту. Цель статьи - определить теоретические основы подготовки будущих специалистов по физическому воспитанию и спорту к профессиональной деятельности. В ходе исследования предусматривалось решение следующих задач: проанализировать научно-методическую литературу по проблеме исследования; выбрать и описать массив базовых терминов, связанных с подготовкой будущих специалистов по физическому воспитанию и спорту к профессиональной деятельности. Для выполнения поставленной цели и решения задач исследования использовался комплекс методов исследования, в частности теоретический анализ, синтез, сравнение, систематизация и обобщение. Результаты. На основе теоретического анализа и обобщения данных энциклопедической, справочной и психолого-педагогической литературы дается характеристика основных понятий образовательной составляющей подготовки будущих специалистов по физическому воспитанию и спорту к профессиональной деятельности. В частности, определяется сущность понятий «учреждение высшего образования», «подготовка», «профессиональная подготовка», «профессиональная подготовка будущих специалистов по физической культуре и спорту», «профессиональная готовность», «готовность к деятельности», «готовность будущих специалистов физического воспитания и спорта к профессиональной деятельности».

В работе используем интегрированные или предложенные другими учеными определения ключевых понятий. «Высшее физкультурное образование» - это целенаправленное формирование знаний, умений и навыков для усвоения социального опыта достижения физического совершенства. «Подготовка» - это процесс, результатом которого является готовность. «Готовность» рассматриваем как «целостное интегрированное качество личности, характеризующее ее эмоционально-когнитивную и волевую выборочную прогнозирующую мобилизациозность в момент включения в деятельность определенной направленности». Под понятием «готовность 
будущих специалистов по физическому воспитанию и спорту к профессиональной деятельности» понимаем комплекс необходимых знаний, умений и способностей, сформированных в результате воспитания и профессионального образования, структурными компонентами которой является психологическая, физическая, теоретическая и практическая готовность.

Ключевые слова: физическая культура, понятие, готовность, профессиональная подготовка, профессиональная деятельность.

Olha Romanchuk, Myroslava Danylevych. Theoretical Grounds of Future Specialists in Physical Education and Sports Readiness Formation for Professional Activities. The need for a clear understanding and differentiation of key concepts and terms for the successful activities of future specialists in physical education and sports has caused the topicality of the paper. The purpose of the article was to determine the theoretical grounds for the training of future specialists in physical education and sport for professional activities. During the study, the following tasks were to be solved: to analyze scientific and methodological literature on the research problem; select and describe an array of basic terms related to the training of future specialists in physical education and sport for their professional activities. To achieve this purpose and to solve the research tasks, a set of research methods was used, in particular: theoretical analysis, synthesis, comparison, systematization and generalization. Results. Based on theoretical analysis and generalization of the data of encyclopedic, reference and psychological and pedagogical literature, the main concepts of the educational component of the training of future specialists in physical education and sport for professional activity have been described. In particular, the essence of the concepts of «higher education institution», «training», «professional training», «professional training of future specialists in physical education and sports», «professional readiness», «readiness for activity», «readiness of future specialists in physical education and sports to professional activity». We rely on the definition of key concepts integrated or suggested by other scholars. «Higher Physical Education» is a purposeful formation of knowledge, skills and abilities for the acquisition of social experience in achieving physical perfection. «Preparation» is a process that results in readiness. «Readiness» is considered as integrated quality of personality, characterizing its emotional, cognitive and volitional selective predictive mobilization at the moment of inclusion in the activity of a certain orientation. Under the notion «readiness of future specialists of physical education and sports for professional activity» we understood the complex of necessary knowledge and abilities formed as a result of general education and professional education, whose structural components are psychological, physical, theoretical and practical readiness.

Key words: physical culture, concept, readiness, professional training, professional activity.

Вступ. Освіта - стратегічний ресурс соціально-економічного, культурного й духовного розвитку суспільства. Відповідно до законів України «Про освіту» (2017), «Про вищу освіту» (2014) та Національної стратегії розвитку освіти в Україні на період до 2021 р. (2013) освіта покликана забезпечувати покращання добробуту людей, захищати національні інтереси, зміцнювати міжнародний авторитет, формувати позитивний імідж нашої держави й створювати умови для самореалізації кожної особистості.

Зміни, що відбуваються в сучасному українському суспільстві, вимагають від випускників закладів вищої освіти високого рівня готовності виконувати професійну діяльність відповідно до європейських стандартів якості [5].

У сучасній соціально-економічній ситуації, як зазначає В. В. Мартиненко, зростає роль вищої фізкультурної освіти, що приводить до актуалізації не лише традиційних, але й професійних функцій педагога (організація змістовної та професійної сторін освіти й соціокультурного середовища) [16, с. 56].

Професійну діяльність фахівців із фізичного виховання та спорту досліджували численні українські (М. В. Дутчак, Л. І. Іванова, Р. П. Карпюк, А. П. Конох, С. Н. Приступа, Н. І. Степанченко, Л. П. Сущенко, О. В. Тимошенко, Б. М. Шиян) і зарубіжні (A. Craft, А. J. Cropley, G. J. Hwang, H. F. Chang, K. Maršíková, G. Moodie та ін.) науковці.

У системі фізкультурної освіти, на думку Г. Шамардіної, здійснюється перехід від традиційного досвіду (у вигляді розвитку рухових фізичних здібностей, умінь, навичок і якостей) до усвідомлення, опанування та створення людиною різноманітних духовних цінностей фізичної культури (культура мислення, уяви, почуття художнього образу тощо) стосовно розвитку досвіду тілесності як фундамент власної культури особистості, якій притаманна свідома діяльність [26, с. 102].

Потреба усвідомлення цілісного процесу професійної підготовки фахівців фізичного виховання та спорту, головних його суперечностей i їх причин потребує осмислення нагромадженого досвіду в контексті його прогресивніших тенденцій, національних особливостей та суттєвих закономірностей [27].

На думку Н. І. Степанченко, «успішне вирішення нових завдань, що стоять перед вищою освітою фізкультурного профілю, залежить від готовності та здатності викладачів здійснювати перехід до 
нового педагогічного мислення, суть якого полягає у сприйнятті навчання як процесу професійного розвитку особистості студента» $[25$, с. 443$]$.

Мета дослідження полягає у визначенні теоретичних основ підготовки майбутніх фахівців із фізичного виховання й спорту до професійної діяльності.

Досягнення мети передбачає виконання таких завдань:

1) проаналізувати науково-методичну літературу з проблеми дослідження;

2) вибрати та описати масив базових термінів, пов'язаних із підготовкою майбутніх фахівців із фізичного виховання й спорту до професійноїдіяльності.

Матеріал та методи. Для досягнення поставленої мети та виконання завдань дослідження використано цілий комплекс методів дослідження, зокрема теоретичний аналіз, синтез, порівняння, систематизацію й узагальнення.

Результати дослідження та їх обговорення. Для з'ясування теоретичних засад підготовки майбутніх фахівців із фізичного виховання та спорту до професійної діяльності ми здійснили аналіз тлумачень ключових понять дослідження, до яких відносимо такі, як «заклад вищої освіти», «вища фізкультурна освіта», «підготовка», «професійна підготовка», «готовність», «професійна готовність», «готовність до діяльності», «готовність до професійної діяльності», «готовність майбутніх фахівців фізичного виховання й спорту до професійної діяльності».

У статті 1 Закону України «Про вищу освіту» (2014) термін «заклад вищої освіти» потрактовано як «окремий вид установи, яка $є$ юридичною особою приватного або публічного права, діє згідно 3 виданою ліцензією на провадження освітньої діяльності на певних рівнях вищої освіти, проводить наукову, науково-технічну, інноваційну та/або методичну діяльність, забезпечує організацію освітнього процесу і здобуття особами вищої освіти післядипломної освіти з урахуванням їхніх покликань, інтересів і здібностей».

Поняття «вища фізкультурна освіта» Н. В. Маковецька тлумачить як «цілеспрямоване формування знань, вмінь і навичок для засвоєння соціального досвіду досягнення фізичної досконалості» [15, с. 119].

Розкриємо сутність поняття «підготовка» й «професійна підготовка».

У «Великому тлумачному словнику сучасної української мови» поняття «підготовка» потрактовано як «запас знань, навичок, досвід, набутий у процесі навчання та практичної діяльності» [1].

В. А. Семиченко у своїх працях звертає увагу на те, що сутність поняття «підготовка» розкривається у двох його значеннях: 1) як навчання - деякий спеціально організований процес формування готовності до виконання майбутніх завдань; 2) як готовність - наявність компетенції, знань, умінь i навичок, необхідних для успішного виконання певної сукупності завдань [22].

У дослідженні використовуватимемо поняття «підготовка» в тлумаченні, поданому Ю. О. Лянним. Учений указує, що «підготовка - це процес, результатом якого є готовність» [14, с. 38].

В «Енциклопедії освіти» поняття «професійна підготовка» потрактовано як сукупність спеціальних знань, умінь і навичок, якостей, трудового досвіду й норм поведінки, які забезпечують можливість успішної праці за обраною професією [9, с. 390].

Нами проаналізовано енциклопедичну та довідкову літературу задля визначення сутності дефініції «готовність».

Для коректного трактування поняття «готовність» уважаємо за необхідне звернутися, передусім, до довідкових джерел. Так, у «Великому тлумачному словнику сучасної української мови» під редакцією В. Т. Бусела готовність визначається як «стан готового; бажання зробити що-небудь» [1, c. 194]; у «Сучасному тлумачному словнику української мови» за редакцією В. В. Дубічинського готовність тлумачиться як «бажання зробити що-небудь» [6, с. 210]; у «Словнику психолого-педагогічних понять і термінів» готовність трактується як стан особистості, який дає їй змогу успішно увійти в професійне середовище, швидко розвиватися в професійному плані [24, с. 20].

Подальший аналіз наукової психолого-педагогічної літератури засвідчив, що дослідники трактують це поняття неоднозначно. Так, наприклад, у вітчизняній психології термін використовують переважно для позначення усвідомленої готовності особистості до оцінок ситуацій і поведінки, зумовлених попереднім досвідом. На сучасному етапі розвитку науки, вважає Т. В. Жванія, дослідниками сформульовано низку сталих визначень «готовності», розкрито іiі зміст, структуру, основні параметри й умови, що впливають на динаміку, тривалість та стійкість її проявів [8].

Існує чимало різних трактувань поняття. Зокрема, Т. Гершкович визначає «готовність» як інтегративну суб'єктну характеристику адаптації, що включає індивідуальні властивості особистості й особливості побудови індивідуальних стратегій адаптації [4]; М. І. Дьяченко та Л. А. Кандибович - як 
цілеспрямований прояв особистості, що містить у собі ii переконання, погляди, мотиви, почуття, вольові й інтелектуальні якості, знання, уміння, навички, налаштування на певну поведінку [7]; Н. Паперна - як складне інтегративне новоутворення особистості, яке передбачає позитивну спрямованість особистості до діяльності.., а також сформованість комунікативних умінь [20, с. 63-64].

Готовність, на думку Д. Вороніна, $є$ вибірковою прогностичною активністю особистості на стадії іiі підготовки до діяльності, котра починається з моменту визначення мети на основі усвідомлення потреб і мотивів та розвивається відповідно до визначених особистістю плану, установок, загальних моделей подальших дій, що втілюються в предметні дії й відповідають чітко визначеним засобам і способам діяльності [3, с. 24].

I. О. Машук тлумачить готовність як «особливий психічний стан, зумовлений комплексом об'єктивних та суб'єктивних чинників, який характеризується оптимальною мобілізацією всіх ресурсів організму й утворюється внаслідок сукупності особистісних якостей та завдяки цілеспрямованій підготовці особистості» [18]. Під сукупністю особистісних якостей науковець розуміє, передусім, професійно значущі якості особистості, у тому числі інтелектуальні й вольові здібності; наявність професійної спрямованості, установок, мотивів, потреб; усвідомлення цілей; наявність професійних знань, умінь і навичок [18].

Л. О. Мацук тлумачить готовність як «результат діяльності вищої педагогічної школи України, як своєрідне професійне новоутворення, що характеризує новий тип особистості вчителя в умовах правової держави 3 пріоритетами гуманізму й демократії» [17, с. 10-11].

Проблему готовності, на думку М. С. Сафіної, дослідники вивчають із різних позицій та відповідно до цього підкреслюють певні характеристики, зумовлені особливостями того аспекту, у контексті якого розглядають це явище [21, с. 44]. На думку науковця, більшість дослідників визначають готовність як якість чи новоутворення особистості, котре має багатокомпонентну структуру [21, с. 44].

Підсумовуючи дослідження в педагогіці й психології, Н. Є. Мойсеюк наголошує, що готовність використовується в таких значеннях, як навченість, підготовленість до виконання майбутніх завдань; наявність компетентності, знань і вмінь, потрібних для виконання поставлених завдань [19, с. 367].

Нам імпонує поняття «готовність» у тлумаченні 3. Н. Курлянда. Учений трактує лексему «готовність» як «цілісну інтегровану якість особистості, що характеризує іiі емоційно-когнітивну та вольову вибіркову прогнозуючу мобілізаційність у момент включення в діяльність певної спрямованості» [12, с. 225].

Науковці розглядають різні види готовності (див. рис. 1).

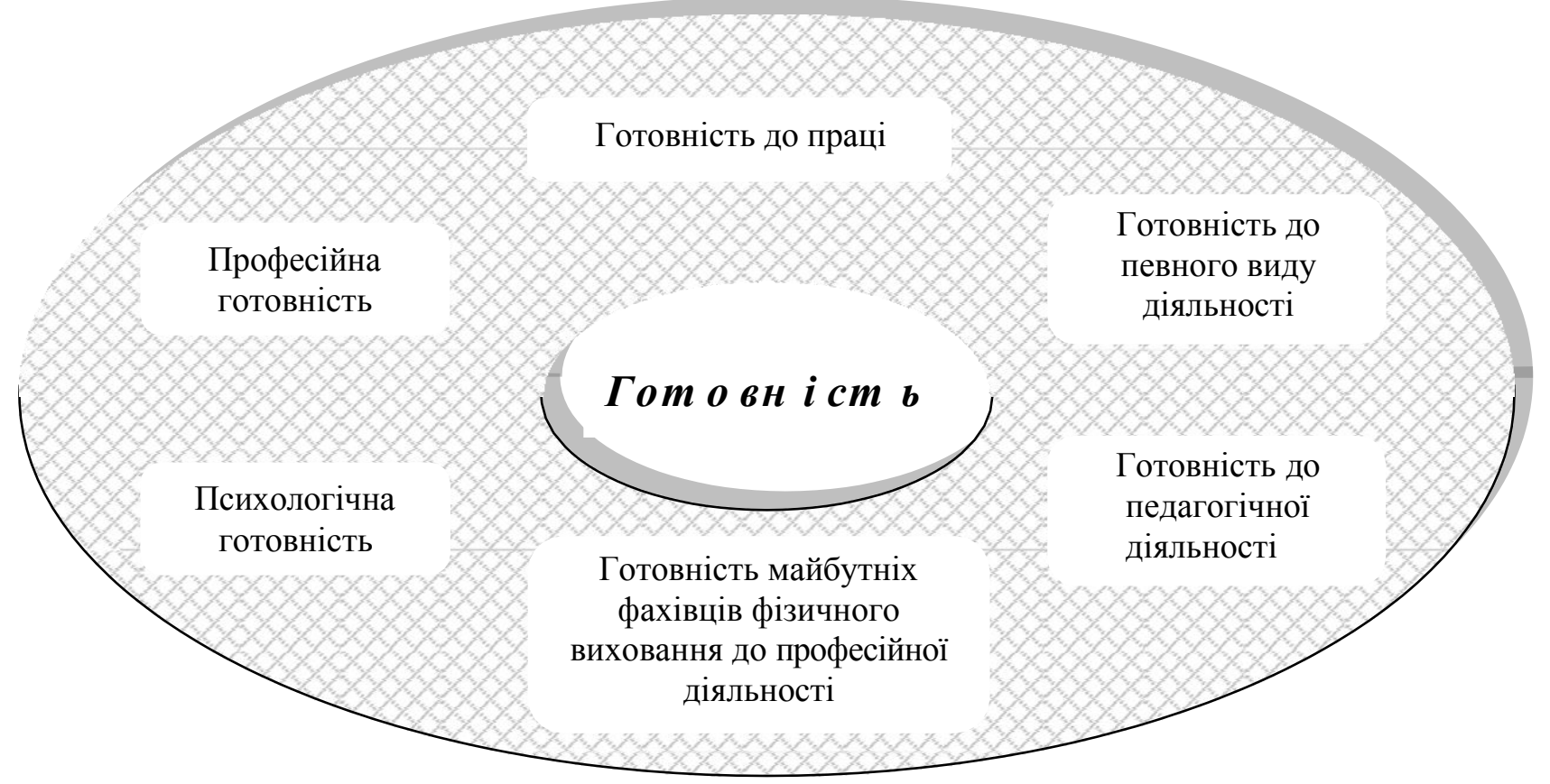

Рис. 1. Види готовності

Термін «професійна готовність» М. І. Дьяченко й Л. А. Кандибович використовують для визначення довготривалої готовності особистості виконувати певні види діяльності, сукупність яких $є$ 
соціально типовою для певної групи соціуму, об’єднаної належністю до певної професії. Перелік видів діяльності, готовність до виконання яких означає професійну готовність, визначається профілем спеціальності [7, с. 16].

Професійна готовність, на думку М. Я. Віленського та І. П. Образцова, є складним синтезом тісно взаємопов'язаних компонентів, які характеризують, насамперед, мотиваційно-ціннісний (особистісний) і виконавський (процесуальний) аспекти діяльності [2, с. 36].

Для нашого дослідження також заслуговує на увагу визначення поняття «готовність до певного виду діяльності».

В «Енциклопедії освіти» під редакцією В. Г. Кременя термін «готовність до діяльності» розглянуто як «стан мобілізації психологічних і психофізіологічних систем людини, які забезпечують виконання певної діяльності» [9, с. 137]. У психології виокремлюють кілька аспектів готовності до діяльності: операційний, мотиваційний, соціально-психологічний, психофізіологічний. Кожний стан готовності до діяльності визначається сполученням різних факторів, що визначають різні рівні, аспекти готовності залежно від змісту діяльності й умов їі здійснення провідним може стати один із таких аспектів [9, с. 137].

Відповідно до змісту завдань, які виконуватимуться суб'єктом діяльності, М. І. Дьяченко й Л. А. Кандибович визначають готовність до того чи іншого виду діяльності як цілеспрямований $\mathrm{i}$ наперед визначений прояв особистості [7, с. 156]. Вони розглядають цей феномен із двох позицій: психічний стан (тимчасова, або ситуативна готовність) і характеристика особистості (довготривала, або загальна). Тимчасова готовність - це актуалізація, пристосування всіх сил, створення психологічних можливостей для успішних дій у момент, наступний за тим, у якому спостерігається готовність. Довготривала готовність - це сукупність набутих установок, знань, навичок, умінь, досвіду, якостей і мотивів діяльності [7, с. 156].

В. О. Сластьонін визначає поняття «готовність до діяльності» як здатність особистості впевнено й ефективно виконувати професійну діяльність, яка містить у собі різні настанови на усвідомлення завдання, моделі ймовірної поведінки, визначення спеціальних засобів діяльності, оцінку своїх можливостей у їх співвідношенні з труднощами та необхідністю досягнення певного результату [23, с. 78]. Ми приєднуємося до такого визначення поняття «готовність до діяльності».

I. А. Кучерявенко стверджує, що стан готовності до діяльності потрібно розуміти як складний, цілеспрямований прояв особистості, що має динамічну структуру, між компонентами якої існують функціональні залежності [13, с. 61]. Людина в практичній діяльності, прагнучи задовольнити власні потреби, на основі внутрішньої активності (біологічної, фізіологічної й психічної) реалізовує поставлену мету та досягає результату [13, с. 61].

Готовність до виконання певної діяльності, як вважає Т. В. Жванія, формується в процесі реалізації цієї діяльності на етапі навчання й уключається до структури діяльності на етапі професійного ії виконання у вигляді специфічного особистісного новоутворення [8].

О. Е. Курлигіна переконана, що готовність до професійної діяльності формується й підтримується в процесі професійного навчання за допомогою виконання вправ, розв'язання спеціальних завдань та інших засобів, що забезпечують залучення знань, умінь і навичок для накопичення досвіду професійної діяльності [11].

Цікавою $є$ думка М. Кулакової, яка в дослідженні розглядає готовність до професійної діяльності 3 позицій управлінського підходу та підкреслює, що така готовність виявляється у формах активності й дає змогу виконувати відповідні типові завдання, прогнозувати способи підвищення продуктивності роботи в професійному напрямі $[10$, с. 20].

У цій науковій роботі ми під поняттям «готовність майбутніх фахівців фізичного виховання та спорту до професійної діяльності» розуміємо комплекс необхідних знань, умінь і здібностей, сформованих у результаті виховання й професійної освіти, структурними компонентами якої виступає психологічна, фізична, теоретична та практична готовність.

Висновки. На основі теоретичного аналізу й узагальнення даних енциклопедичної, довідкової та психолого-педагогічної літератури схарактеризовано основні поняття освітянської складової частини підготовки майбутніх фахівців із фізичного виховання й спорту до професійної діяльності. Зокрема, визначено сутність понять «заклад вищої освіти», «підготовка», «професійна підготовка», «професійна підготовка майбутніх фахівців із фізичного виховання та спорту», «професійна готовність», «готовність до діяльності», «готовність майбутніх фахівців фізичного виховання та спорту до професійної діяльності». Акцентовано увагу на тому, що професійна підготовка $\epsilon$ системою навчання або процесом отримання майбутнім фахівцем спеціальних знань, умінь і навичок, особистісно-професійних якостей, що забезпечують можливість успішної роботи з певної професії. 


\section{Джерела та література}

1. Бусел В. Т. Великий тлумачний словник сучасної української мови. Київ; Ірпінь: Перун, 2005. 1728 с.

2. Виленский М. Я., Образцов П. И., Уман А. И. Технология профессионально-ориентированного обучения в высшей школе. Орел: ОГУ, 2010. 420 с.

3. Воронін Д. Питання готовності вчителів фізичної культури до професійної діяльності. Фізичне виховання, спорт і культура здоров’я у сучасному суспільстві. 2011. № 2(14). С. 24-25.

4. Гершкович Т. Б. Формирование готовности к педагогической деятельности и ее связь с индивидуальными стратегиями адаптации: автореф. дис. ... канд. психол. наук. Казань, 2002. 20 с.

5. Данилевич М. В. Професійна підготовка майбутніх фахівців з фізичного виховання та спорту до рекреаційно-оздоровчої діяльності: теоретико-методичний аспект: монографія. Львів: Піраміда, 2018. 460 с.

6. Дубічинський В. В. Сучасний тлумачний словник української мови: 65000 слів. Харків: Школа, 2006. $1008 \mathrm{c}$.

7. Дьяченко М., Кандыбович Л. Психологический словарь-справочник. Минск: Харвест; Москва: АСТ, 2001. $576 \mathrm{c.}$

8. Жванія Т. В. Готовність до професійної діяльності в психології: теоретичний аналіз. Вісник Харківського начіонального педагогічного університету імені Г. С. Сковороди. Серія: Психологія. 2015. Вип. 50. С. 6979. URL: http://nbuv.gov.ua/UJRN/VKhnpu_psykhol_2015_50_11 (дата звернення: 18.04.2016)

9. Кремень В. Г. Енциклопедія освіти. Київ: Юрінком Інтер, 2008. 1040 с.

10. Кулакова М. В. Формування готовності до професійної діяльності в майбутніх фахівців у вищих морських навчальних закладах: дис. ... канд. пед. наук. Одеса, 2006. 225 с.

11. Курлыгина О. Е. Компетентность как характеристика готовности будущего учителя к осуществлению профессиональной деятельности. Современные проблемы науки и образования. 2014. № 4. С. 34-38.

12. Курлянд 3. Н. Педагогіка вищої школи: навч. посіб. 2-ге вид., доповн. та переробл. Київ: Знання, 2005. $399 \mathrm{c.}$

13. Кучерявенко И. А. Проблема психологической готовности к профессиональной деятельности. Молодой ученый. 2011. № 12(2). С. 60-62.

14. Лянной Ю. О. Професійна підготовка майбутніх магістрів 3 фізичної реабілітації у вищих навчальних закладах: теоретико-методичний аспект: монографія. Суми: Вид-во СумДПУ ім. А. С. Макаренка, 2016. $566 \mathrm{c}$.

15. Маковецька Н. В. Формування фізичної культури і здорового способу життя особистості: теоретичний аспект проблеми. Педагогіка, психологія та медико-біологічні проблеми фізичного виховання $i$ спорту. 2006. № 10. C. 117-121.

16. Мартиненко В. В. Проблеми неперервної професійної підготовки фахівців фізичного виховання і спорту. Педагогіка, психологія та медико-біологічні проблеми фізичного виховання і спорту. 2006. № 3. С. 55-58.

17. Мацук Л. О. Підготовка майбутніх учителів початкових класів до правового виховання молодших школярів: автореф. дис. ... канд. пед. наук. Тернопіль, 2002. 20 с.

18. Машук I. О. Формування психологічної готовності учнів спеціалізованих загальноосвітніх закладів міліції до навчально-службової діяльності в системі МВС України: автореф. дис. ... канд. психол. наук. Київ, 2009. $20 \mathrm{c}$.

19. Мойсеюк Н. С. Готовність до професійної діяльності: суть і шляхи формування. Сучасні інформаційні технології та інноваційні методики навчання у підготовці фахівців: методологія, теорія, досвід, проблеми. Київ; Вінниця, 2006. Вип. 12. С. 364-368.

20. Паперная Н. В. Формирование готовности будущего учителя к межкультурной коммуникации: дис. ....канд. пед. наук. Армавир, 2002. 197 с.

21. Сафина М. С. Формирование готовности к межкультурной коммуникации у студентов гуманитарных вузов (на материале изучения иностранного языка): дис. ... канд. пед. наук. Казань, 2005. 181 с.

22. Семиченко В. А. Проблеми і пріоритети професійної підготовки. Педагогічний дискурс. 2007. Вип. 1. C. $119-127$.

23. Сластѐнин В. А. Педагогика профессионального образования: учеб. пособие. Москва: Академия, 2004. $368 \mathrm{c}$.

24. Словник психолого-педагогічних понять і термінів. 2003. URL: http://osvita.ua/school/method/psychology/ 1270/ list/1(дата звернення: 10.10.2016).

25. Степанченко Н. І. Основні напрями вищої освіти з фізичного виховання в контексті ідей нової освітньої парадигми. Сучасні інформаційні технологї та інноваційні методики навчання у підготовцุі фахівців: методологія, теорія, досвід, проблеми. 2014. Вип. 38. С. 439-446.

26. Шамардіна Г. Теорія концепції освітньої сфери фізичної культури. Педагогіка, психологія та медикобіологічні проблеми фізичного виховання і спорту. 2003. № 15. С. 101-106.

27. Protsenko U., Pantiuk T., Romanchuk O., Danylevych M. Improvement features of the Ukrainian physical education system. Journal of Physical Education and Sport. 2016. Vol. 16(1). P. 19:113-117. https://doi.org/ 10.7752 / jpes.2016.01019. 


\section{References}

1. Busel, V. T. (2005). Velykyi tlumachnyi slovnyk suchasnoi ukrainskoi movy [Great Explanatory Dictionary of Modern Ukrainian Language]. Kyiv; Irpin: Perun, 1728.

2. Vylenskyi, M. Ya., Obraztsov, P. Y., Uman, A. Y. (2010). Tekhnolohija professyonalno-oryentyrovannoho obuchenyia $v$ vysshei shkole [Technology of vocational-oriented education in higher education academy]. Orel: $\mathrm{OHU}, 420$.

3. Voronin, D. (2011). Pytannia hotovnosti vchyteliv fizychnoi kultury do profesiinoi diialnosti [The issue of the readiness of teachers of Physical Culture for professional activity]. Fizychne vykhovannia, sport $i$ kultura zdorovia u suchasnomu suspilstvi, no. 2(14), 24-25.

4. Hershkovych, T. B. (2002). Formyrovanie hotovnosti $k$ pedahohycheskoi deiatelnosty $i$ ee sviaz' $s$ yndyvidualnymi stratehyiami adaptatsii [Formation of readiness for pedagogical activity and its connection with individual adaptation strategies]. (Avtoref. kand. psykhol. nauk). Kazan, 20.

5. Danylevych, M. V. (2018). Profesiina pidhotovka maibutnikh fakhivtsiv z fizychnoho vykhovannia ta sportu do rekreatsiino-ozdorovchoi diialnosti: teoretyko-metodychnyi aspekt [Professional training of future specialists in Physical Education and Sports for recreational and health-improving activities: theoretical and methodical aspect]. Lviv: Piramida, 460.

6. Dubichynskyi, V. V. (2006). Suchasnyi tlumachnyi slovnyk ukrainskoi movy [Modern Monolingual Dictionary of Ukrainian Language]. (65000 sliv). Kharkiv: Shkola, 1008.

7. Diachenko, M., Kandybovych, L. (2001). Psykholohycheskyi slovar-spravochnyk [Psychological Reference Dictionary]. Mynsk: Kharvest; Moskva: AST, 576.

8. Zhvaniia, T. V. (2015). Hotovnist` do profesiinoi diialnosti v psykholohii: teoretychnyi analiz [Readness for the profession of psychology: theoretical analysis]. Visnyk Kharkivskoho nats. ped. un-tu imeni H. S. Skovorody. Seriia: Psykholohiia. Vyp. 50, 69-79.

9. Kremen, V. H. (2008). Entsyklopediia osvity [Encyclopedia of Education]. Kyiv: Yurinkom Inter, 1040.

10. Kulakova, M. V. (2006). Formuvannia hotovnosti do profesiinoi diialnosti v maibutnikh fakhivtsiv u vyshchykh morskykh navchalnykh zakladakh [Formation of preparedness for professional activity of future specialists in higher marine educational institutions]. (Dys. kand. ped. nauk). Odesa, 225.

11. Kurlyhina, O. E. (2014). Kompetentnost' kak kharakterystyka hotovnosti budushcheho uchytelia k osushchestvleniju professyonalnoi deiatelnosti [The competence as a characteristic of the readiness of the future teacher for professional activities implementation]. Sovremennye problemy nauki i obrazovaniya, No. 4, 34-38.

12. Kurliand, Z. N. (2005). Pedahohika vyshchoi shkoly [High School Pedagogy]: navch. posib. (2-e vyd., dop. ta pererobl.). Kyiv: Znannia, 399.

13. Kucheriavenko, Y. A. (2011). Problema psykholohycheskoi hotovnosti k professyonalnoi deoatelnosty [The problem of psychological readiness for professional activity]. Molodoi uchenyi, No. 12(2), 60-62.

14. Liannoi, Yu. O. (2016). Profesiina pidhotovka maibutnikh mahistriv z fizychnoi reabilitatsii u vyshchykh navchalnykh zakladakh: teoretyko-metodychnyi aspekt [Professional training of future Masters on Physical Rehabilitation in higher educational institutions: theoretical and methodical aspect]. Sumy: Vyd-vo SumDPU, 566.

15. Makovetska, N. V. (2006). Formuvannia fizychnoi kultury i zdorovoho sposobu zhyttia osobystosti: teoretychnyi aspekt problemy [Formation of physical culture and healthy lifestyle of personality: the theoretical aspect of the problem.]. Pedahohika, psykholohiia ta medyko-biolohichni problemy fizychnoho vykhovannia i sportu, No. 10, $117-121$.

16. Martynenko, V. V. (2006). Problemy neperervnoi profesiinoi pidhotovky fakhivtsiv fizychnoho vykhovannia i sportu [Problems of continuous professional training of Physical Education and Sports specialists]. Pedahohika, psykholohiia ta medyko-biolohichni problemy fizychnoho vykhovannia i sportu, no. 3,55-58.

17. Matsuk, L. O. (2002). Pidhotovka maibutnikh uchyteliv pochatkovykh klasiv do pravovoho vykhovannia molodshykh shkoliariv [Preparation of future primary school teachers for legal education of junior pupils]. Avtoref. kand. ped. nauk. Ternopil, 20.

18. Mashuk, I. O. (2009). Formuvannia psykholohichnoi hotovnosti uchniv spetsializovanykh zahalnoosvitnikh zakladiv militsii do navchalno-sluzhbovoi diialnosti v systemi MVS Ukrainy [Formation of psychological readiness of pupils of specialized secondary police schools for educational and service activity in the system of the Ministry of Internal Affairs of Ukraine]. Avtoref. kand. psykhol. nauk. Kyiv; Vinnytsia. Vyp. 12, 364-368.

19. Moiseiuk, N. Ye. (2006). Hotovnist do profesiinoi diialnosti: sut $\mathrm{i}$ shliakhy formuvannia [Readiness for professional activity: the essence and ways of its formation]. Suchasni informatsiini tekhnolohii ta innovatsiini metodyky navchannia u pidhotovtsi fakhivtsiv: metodolohiia, teoriia, dosvid, problemy. Kyiv; Vinnytsia, Vyp. 12, 364-368.

20. Papernaia, N. V. (2002). Formyrovanye hotovnosty budushcheho uchytelia k mezhkulturnoi kommunykatsyy [Formation of readiness of the future teacher for intercultural communication]. Dys. kand. ped. nauk. Armavyr, 197.

21. Safina, M. S. (2005). Formyrovanie hotovnosti k mezhkulturnoi kommunykatsii u studentov humanytarnykh vuzov (na materyale izuchenyia inostrannoho yazyka) [The formation of readiness for intercultural 
communication among students of the humanitarian academic institutions (on the materials of foreign language studying)]. Dys. kand. ped. nauk. Kazan`, 181.

22. Semychenko, V. A. (2007). Problemy i priorytety profesiinoi pidhotovky [Problems and priorities of professional training]. Pedahohichnyi dyskurs, Vyp. 1, 119-127.

23. Slastienyn, V. A. (2004). Pedahohyka professyonalnoho obrazovanyia [Pedagogy of vocational education]. Ucheb. Posobiye. Moskva: Akademyia, 368.

24. Slovnyk psykholoho-pedahohichnykh poniat i terminiv [Dictionary of psychological and pedagogical concepts and terms]. (2003). URL: http://osvita.ua/school/method/psychology/1270/ list/1.

25. Stepanchenko, N. I. (2014). Osnovni napriamy vyshchoi osvity z fizychnoho vykhovannia v konteksti idei novoi osvitnoi paradyhmy [The main directions of higher education on Physical Education in the context of ideas of a new educational paradigm]. Suchasni informatsiini tekhnolohii ta innovatsiini metodyky navchannia u pidhotovtsi fakhivtsiv: metodolohiia, teoriia, dosvid, problemy, Vyp. 38, 439-446.

26. Shamardina, H. (2003). Teoriia kontseptsii osvitnoi sfery fizychnoi kultury [The theory of the concept of Physical Culture in the educational field]. Pedahohika, psykholohiia ta medyko-biolohichni problemy fizychnoho vykhovannia $i$ sportu, no.15, 101-106.

27. Protsenko, U., Pantiuk, T., Romanchuk, O., Danylevych, M. (2016). Improvement features of the Ukrainian physical education system. Journal of Physical Education and Sport, Vol. 16 (1),113-117. https://doi.org/ 10.7752/jpes.2016.01019.

Стаття надійшла до редакції 20.03.2019 р. 